Letrônica, Porto Alegre, v. 7, n. 1, p. 130-154, jan./jun., 2014

\title{
AN INVESTIGATION ON HOW BRAZILIAN UNIVERSITY-LEVEL STUDENTS PRODUCE WRITTEN SUMMARIES OF AN EXPOSITORY TEXT IN L2
}

\author{
UM ESTUDO SOBRE COMO ESTUDANTES UNIVERSITÁRIOS BRASILEIROS \\ PRODUZEM RESUMOS ESCRITOS DE UM TEXTO EXPOSITIVO EM INGLÊS (L2)
}

\author{
Cyntia Bailer* \\ Claudia Marchese Winfield* \\ Fabiana Vanessa Achy de Almeida* \\ Deise Caldart Roscioli*
}

\begin{abstract}
Ideally, readers build meaningful and coherent mental representations of the texts they read (KINTSCH; VAN DIJK, 1978; VAN DIJK; KINTSCH, 1983; GAGNÉ et al., 1993); and they are able to express such mental representations in summaries and recall protocols. Furthermore, strategic readers approach a text while keeping in mind the situation in which they are reading, i.e., reading purposes and text type, and while monitoring their comprehension (CARRELL, 1989; 1998; PARIS; LIPSON; WIXSON, 1983; PARIS; WASIK; TURNER, 1991). The present study aims at investigating to what extent eight Brazilian university-level students are strategic when producing written summaries of an expository text in English as L2. Participants were enrolled in a workshop on writing summaries about expository texts in English; their text production was collected and analyzed in terms of their strategies for identifying controlling, central and secondary ideas. Participants were proficient and strategic readers in both their L1 (Portuguese) and L2 (English), and were knowledgeable about academic genres. Our hypothesis was that the readers would be able to construct a meaningful and coherent representation of the text while monitoring their reading comprehension. The process of monitoring comprehension would be reflected in the reader's summaries. Results revealed that the majority of the participants adopted strategies when approaching the text, and that they were able to build a coherent mental representation of the text; however, results also suggest some readers omitted central and secondary ideas.
\end{abstract}

Keywords: Reading comprehension and production; Summary; L2 university students; Expository texts.

Resumo: Numa situação ideal, os leitores constroem representações mentais significativas e coerentes dos textos que eles leem (KINTSCH; VAN DIJK, 1978; VAN DIJK; KINTSCH, 1983; GAGNÉ et al., 1993) e são capazes de expressar essas representações mentais através da elaboração de resumos e atividades de recordação (recall). Ademais, leitores estratégicos abordam um texto tendo em mente a situação de leitura, isto é, os objetivos e o tipo de texto, enquanto monitoram sua compreensão (CARRELL, 1989; 1998; PARIS, LIPSON; WIXSON,

\footnotetext{
* PhD candidates at PPGI - Programa de Pós-Graduação em Inglês, from Universidade Federal de Santa Catarina, Florianópolis, Brazil - participants of the Núcleo de Estudos em Leitura (NEL) advised by Professor Lêda Maria Braga Tomitch. Emails: cyntiabailer@gmail.com, claumwin@gmail.com, almeida.fabiana@uol.com.br $\underline{\text { deise.caldart@hotmail.com. }}$

We would like to thank two anonymous reviewers for their insightful comments on a previous version of this article.
} 
1983; PARIS; WASIK; TURNER, 1991). O presente estudo objetiva investigar quão estratégicos oito estudantes brasileiros de nível universitário se mostram ao produzir resumos escritos de um texto expositivo em L2, inglês. Esses estudantes participaram de uma oficina sobre como escrever resumos de textos expositivos em inglês e suas produções foram coletadas e analisadas em termos de conter as ideias controladoras, centrais e secundárias. Os participantes se mostraram leitores proficientes e estratégicos em L1 e L2 (português e inglês, respectivamente), além de familiarizados com os gêneros acadêmicos. Por este motivo, nossa hipótese era de que eles seriam capazes de construir uma representação significativa e coerente do texto apresentado, enquanto monitoravam sua compreensão leitora, a qual poderia ser acessada por meio dos seus resumos. Os resultados revelaram que a maioria dos participantes são estratégicos e conseguiram construir essa representação mental coerente do texto, enquanto alguns omitiram algumas ideias centrais e secundárias.

Palavras-chave: Compreensão leitora e produção textual; Resumo; Estudantes universitários; L2; Textos expositivos.

\section{Introduction}

Reading is considered an interactive process between the reader and the text (AEBERSOLD; FIELD, 1997); thus, reading is viewed as a complex cognitive process, rather than a final product to be analyzed (TOMITCH, 2008). In this sense, strategic reading is believed to take place when the reader takes into account the reading situation, contemplating the purpose in reading and the type of text, so as to determine how to approach it, as well as which strategies to apply. Moreover, the strategic reader observes the reading process and adjusts his/her behavior to achieve the ultimate goal of reading comprehension (CARRELL, 1989 and 1998; PARIS; LIPSON; WIXSON, 1983; PARIS; WASIK; TURNER, 1991).

Following this perspective, each reader constructs meaning(s) from texts influenced by various intrinsic and extrinsic aspects, which are related to the reader, the text, and the cognitive processes involved in the construction of meaning. Some of these aspects include metacognition of the reading process, working memory capacity, world knowledge, genre, text organization, and reading purpose. Our assumption is twofolded: those aspects directly impact the reading comprehension process, which in turn, lead us to conclude that the comprehension process differs from one reader to another.

Devine (1998) states that the ability to create meaning depends on the interaction between the reader's previous knowledge and the information presented in the text. This opinion is shared by Koda (2008), who claims that comprehension is "a meaning-construction process, involving integral interaction between text and reader" (p. 254). The text itself only has 'meaning potential' (HALLIDAY, 1973, as cited in COHEN 
et al., 1998), that is, the interpretation of the reader may not be exactly the one envisaged by the writer, and distinct readers may have different interpretations about a same text due to their distinct background knowledge. Urquhart and Weir (1998) confirm Halliday's ideas regarding the possibility of numerous interpretations, claiming that:

Texts do not have unitary meanings potentially accessible to all, they rather allow for variety in interpretations by different readers, governed by factors such as purpose, background knowledge, and the relationship established between the reader and the writer (p. 112).

Hence, it is possible to assume that the process of constructing meaning is dynamic, and therefore cannot be predicted by the writer. Meaning can differ from reader to reader, and can even be different for a same reader when approaching the same text a further time and with a different purpose.

Strategic readers select the most suitable strategies to approach the reading situation at hand. Additionally, the reader may or may not be aware of his/her strategic reading behavior, which is the result of those intrinsic and extrinsic factors mentioned above (ALMEIDA, 2010). The reader processes the sentences in the page while establishing relations between them, selecting relevant information, deleting overlapping ideas, generalizing detailed information and, thus, constructing a meaningful mental representation of the text being read (KINTSCH; VAN DIJK, 1978). As well, the reader integrates text information to her/his background knowledge, building a situation model of the text (VAN DIJK; KINTSCH, 1983).

Nonetheless, we underscore that this is an ideal situation in which readers efficiently accomplish the reading goal of understanding the text while applying effective strategies. Some students do not possess enough awareness of the reading process to analyze the reading situation and choose how to proceed with it. This may happen because students may not have been taught what (learning and reading) strategies are and how to use them according to the (learning) reading situation. To make matters worse, learners may lack background knowledge of the topic, they may not be familiarized with the vocabulary, the text level may be above the reader's proficiency level, or they may not be sufficiently focused or interested on the topic of the text.

Reading situations encountered by university students offer an example that combines the aforementioned difficulties of lack of knowledge in a specific topic and no 
formal training in effective reading strategies. If we take into account that those students may have reading assignments that include texts in a second language, we can predict that university students may benefit from explicit teachings of reading strategies (CARRELL, 1998; CARRELL; DEVINE; ESKEY, 1998; ESKEY; GRABE, 1998). Bearing that in mind, we offered university students from UFSC - Universidade Federal de Santa Catarina - a workshop that focused on effective summary production of academic texts that were written in English.

The workshop included comprehension strategies that are specific for summary production (KINSTCH; VAN DIJK, 1978). The workshop had two main objectives; the first one was to offer university students a workshop that would give them a chance to learn about well-established models of comprehension that focused in summarization processes, namely the textbase model (KINTSCH; VAN DIJK, 1978) and the situation model (VAN DIJK; KINTSCH, 1983), and to teach students specific reading strategies (HILL; SOPPELSA; WEST, 1982). Familiarization and understanding of the textbase and situation models together with the knowledge of relevant reading strategies potentially inform students' future summarization practices and maybe foster their metacognition (ALMEIDA, 2010).

The second objective of the workshop was to examine the summary produced by the aforementioned group of Brazilian university students who were introduced to summarization strategies (HILL et al., 1982; KINTSCH; VAN DIJK, 1978). The ultimate aim was to ascertain whether explicit teaching had a positive impact in the summaries produced by students.

Researchers who seek to understand how coherent mental representations are built generally as the aftermath of reading comprehension often use think-aloud protocols to investigate online processing, as well as recall and summarization tasks to assess the mental representation of narrative and expository texts. According to Scherer and Tomitch (2008), the researcher may use 'productive tasks' to analyze the situation model, and those include resolution of questions that require problem solution, as well as the elaboration of summaries. In addition, these tasks may be sorting tasks that require participants to choose and group vocabulary departing from a specific topic. In fact, summary tasks are accepted as valid means of assessment of global comprehension, which allow the researcher to observe how readers identified controlling and central 
ideas in the text, which, in turn, are indicators of comprehension (BARETTA, 1998; SCHERER; TOMITCH, 2008; WINFIELD, 2010).

Taking these considerations into account, the present study aims at investigating to what extent Brazilian university-level students are strategic when summarizing an expository text. We understand that summarizing is a productive task, since the textual information is restructured and reorganized in memory in a different way from the original text. It means that as readers we do not keep words active in memory as they appear in the text, but the propositional ideas (KINTSCH; VAN DIJK, 1978) evoked by those words in the text. Besides, the production of a summary requires comprehension abilities, such as the identification of central ideas, in a local and global level and the activation of background knowledge, so that the reader is able to construct a meaningful and coherent mental representation of the text while strategically orchestrating the information from the text with the previous information from his/her schemata. Briefly speaking, Rumelhart (1981) explains that schemata refer to the representation of generic concepts stored in memory, which comprise all previous experiences, and is indispensable for information processing. It is hypothesized that the participants of this study, as university-level students, will be strategic enough to produce effective summaries, in terms of displaying the controlling idea (CRI), the central (CI) and secondary ideas (SI) of the expository text read.

In the next section, we succinctly present the theoretical background that supports the development of this study. We discuss models of discourse comprehension and production and the component process of reading comprehension, we briefly review the literature on strategic reading behavior and we address summary as a measure of reading comprehension.

\section{Review of the literature}

\subsection{Models of discourse comprehension and production and the component processes of reading comprehension}

Kintsch and van Dijk (1978) proposed a model that describes "the system of mental operations" (p. 363) that allows processes to occur during text comprehension 
and production. According to them, the processing model consists of three sets of operations happening in cycles: (1) a first set of operations organizes the meaning elements of the text into a coherent whole. Some elements are processed to construct the interpretation of the text, while others are disregarded. Each reader may construct a different interpretation, retaining certain elements in detriment of others depending on aspects such as reading purpose, degree of familiarity, level of text difficult, to mention a few; (2) a second set of operations reduces the whole meaning of the text into a gist (macrostructure); and (3) a third set of operations generates new texts from the memory as a result of comprehension processes, since readers draw on inferences while reading, building the meaning representation of the text. The authors postulate that "several complex processes operate[ing] in parallel and interactively without straining the resources of the system" (KINTSCH; VAN DIJK, 1978, p.364).

The model proposed by Kintsch and van Dijk (1978) is concerned with semantic structures, which are the result of processing. These semantic structures are characterized at two levels, the level of microstructure and of macrostructure. The microstructure involves the local level of discourse and the structure of the individual propositions and their relations, which is often referred to as cohesion. For the authors, propositions are defined as (1) the result of processing, (2) coherent structured units at the sentence level, (3) as units of basic meaning. According to Tomitch (2012, personal communication), propositions are complete ideas. In this line, the textbase (KINTSCH; VAN DIJK, 1978) is understood as the hierarchically organized set of propositions from the text surface, including the connections between them.

The macrostructure refers to the global level of discourse, the discourse as a meaningful whole, which is frequently referred to as coherence in the literature. Both levels relate to semantic mapping rules, the macrorules, on the grounds that the discourse is expected to be coherent and propositions should be connected and globally organized at the macrostructure level so that a meaningful mental representation of the text is built. At the macrolevel, the macrorules involve: (1) the deletion of detailed and redundant information, as Kintsch and van Dijk (1978, p. 366) state: "each proposition that is neither a direct nor an indirect interpretation of a subsequent proposition may be deleted"; (2) generalization using superordinate terms or categorizations, as the authors state (KINTSCH; VAN DIJK, 1978, p. 366) "each sequence of propositions may be 
substituted by the general proposition denoting an immediate superset"; and (3) the construction of a topic sentence when that is not provided in the text, as the authors postulate that "each sequence of propositions may be substituted by a proposition denoting a global fact" (KINTSCH; VAN DIJK, 1978, p. 366).

The operations cited above are applied under the control of schemata and world knowledge since readers have certain standards for coherence they attempt to achieve that fit their purpose for reading. According to van den Broek, Risden and HusebyeHartmann (1995) standards for coherence refer to the level of understanding that the reader tries to attain while reading. As a consequence, the strictness of the standard impacts the type and quality of the mental representation that the reader constructs.

Van Dijk and Kintsch (1983) further developed the model of semantic representation into the situation model. The situation model encompasses the result of the interaction between the construction of a textbase and the construction of a general understanding of the text based on background knowledge. The construction of a coherent situation model requires the reader to perceive the text as a coherent whole at the same time s/he is building a textbase. Following Winfield (2010, p. 37), this study presupposes that "successful readers are able to build a coherent mental representation of the text by constructing a text base and integrating it with their background knowledge, expressing such mental representation in their summaries".

In the following subsection, we discuss strategic reading behavior and the types of knowledge necessary for the reader to construct a meaningful mental representation of the text.

\subsection{Strategic Reading Behavior}

The dichotomy between skills and strategies has been widely debated in the reading literature (CARRELL, 1989; 1998; COHEN, 1998; PARIS et al., 1983; PARIS et al., 1991; ROSENSHINE; MEISTER, 1997; TOMITCH, 2002) and it is apparently agreed that awareness of the behavior and intention to achieve a given goal are essential characteristics to distinguish skills and strategies. For the purposes of the present study, we follow Almeida (2010) in which skills and strategies are distributed in a continuum as skills refer to more automatic reading processes that occur without the reader's 
awareness, whereas strategies encompass intentional actions that the reader chooses to take while reading (see Almeida, 2010 for a thorough review of the theme). Additionally, the author stresses that what characterizes a strategic reader is that s/he not only knows what strategies to apply, but also knows how to adjust his/her reading behavior during the reading process in agreement with the reading situation. In other words, a proficient (strategic) reader monitors for comprehension throughout the reading process.

In this vein, Paris et al. (1983) underscore that comprehension monitoring seems to be the core issue that characterize proficient readers. The authors observe that strategic readers possess metacognitive skills in the sense that they are aware of which strategies to apply to achieve the reading purpose while monitoring for comprehension. It is the purpose of this study to explore the extent to which students at the tertiary level were able to effectively employ strategies to help them identify the main ideas in the text in order to write summaries with the load of reading and writing in a foreign language ${ }^{1}$.

In this context, and bearing in mind the considerations described above on constructing a meaning mental representation of the text and the metacognitive abilities that typify strategic readers, Gagné, Yekovich and Yekovich (1993) view reading comprehension as the construction of an adequate mental model of the text, relying on the interplay between declarative knowledge (DK) and procedural knowledge (PK). In proficient reading, the processes happen in parallel. According to Gagné et al. (1993), DK corresponds to knowing that something is the case, knowing about facts, theories, and being able to verbalize such knowledge. DK involves all we know about letters, phonemes, morphemes, words, ideas, schemas and topics, and it consists of either a basic unit level of knowledge, such as propositions, imagery, or linear orderings; or to schemata, that is, when several units are combined in an integrated and organized structure of knowledge.

Procedural knowledge accounts for knowing how to do things, and differently from DK, verbalization of PK decays as the process becomes more automatized.

\footnotetext{
1 Due to space and time constraints, we are not discussing the dichotomy found in the literature concerning Second Language Acquisition between second language, foreign language and additional language, although we acknowledge that it exists. For the purposes of this study, we will use the terms interchangeably. Similarly, we are not discussing the implications of reading and writing in a foreign language in which cross-linguistic transfers from Portuguese to English, and vice-versa, may occur and, therefore, aid or impair reading comprehension and its outcome, i.e., the production of summaries.
} 
Following Gagné et al. (1993), PK includes the component process of reading: (a) decoding, the lowest level process, is subdivided into matching and recoding; (b) literal comprehension, subdivided into lexical access and parsing; (c) inferential comprehension, subdivided into integration, summarization and elaboration; and (d) comprehension monitoring, the highest level process, is subdivided into setting a goal, selecting strategies, checking goal and remediating if necessary. Of special importance for this study is the subcomponent summarization, since it involves the production of necessary inferences ${ }^{2}$ so that the reader is able to extract the essence of the text, in order to produce a coherent mental representation of the content of the text.

\subsection{Summary as a measure of comprehension}

Summaries are considered valid measures of reading comprehension (WINFIELD, 2010) and are tightly connected to studies about writing (EISTERHOLD, 1990; WINFIELD, 2010). Although we believe that summaries lie in the interface between reading and writing, the relationship between the two activities is not straightforward, especially when it comes to readers being able to transfer their reading processes from L1 to a second language. For this reason, Eisterhold (1990) supports that students should be explicitly taught how to read and write, meaning that students are to be exposed to a certain variety of text genres in which they are systematically and structurally taught how to read and write.

For instance, students should learn strategies as setting reading/writing purposes, identifying the audience, identifying text structure, to mention but a few useful strategies. Besides, students that display difficulty in reading and comprehending are likely to present a similar difficulty when asked to produce the same text genre. Studies as the one conducted by Koerich and Dellagnelo (2008) also indicate that there is a complex connection between reading and writing. The authors perceived that students had difficulties in identifying the central ideas of a text when producing summaries, hence, their study aimed at comparing the summaries produced by Brazilian

\footnotetext{
2 For the purpose of this study the term inference refers to "any information about events, relations, and so on that the reader adds to the information that is explicitly presented in the text" (VAN DEN BROEK, et al., 1995, p. 353). Koda (2008) complements this definition stating that inference generation is a part of the reading process and is crucial for 'text-meaning construction'.
} 
ESP students in Portuguese and in English. Results revealed that participants produced list-like summaries, since they attempted to recall as much information as possible rather than the central ideas of the text. It seems that participants lacked the ability to differentiate relevant from irrelevant information and, despite acquainted with the genre summary, they were not able to produce a good one. It is believed that the distinction between relevant and irrelevant information directly impacts writing in terms of production of the genre and clarifies one aspect of the reading ability that directly influences writing. Furthermore, it is relevant to highlight that some degree of metalinguistic awareness is necessary for the reader to be able to notice the nuances of the material he/she reads, being able to produce similar ones afterwards.

According to Koerich and Dellagnelo (2008), studies about summary production reveal mixed results due to a lack of systematization of the instrument. They explain that some researchers have asked participants to produce summaries immediately after reading with access to the original text, while other researchers proposed the production of summaries immediately after reading the original text, but without access to it during the production. In addition to that, other researchers proposed studies involving summaries production after a recall task. Despite these methodological issues, some findings are significant; as the finding that instruction about the abilities related to the writing of summaries is considered effective to the identification of main ideas and that the identification of main ideas is relevant to the production of summaries (KOERICH; DELLAGNELO, 2008). Nevertheless, more studies are needed to help us better understand how learners produce summaries, especially in an L2.

\section{Method}

This study aims at investigating to what extent Brazilian university-level students are strategic in producing written summaries of an expository text. As the participants are undergraduate and post-graduate students, used to reading in L1 (Portuguese) and L2 (English), especially academic texts, it is hypothesized that the readers will be able to construct a meaningful and coherent representation of the text, reflected in their production of summaries. 


\subsection{Research design, instruments and procedures}

Data collection was carried out during a workshop entitled "How to write effective summaries in English as a foreign language?" (for the abstract submitted to the evaluation committee see the Appendix) conducted by the authors of this article, held in the $11^{\text {th }}$ SEPEX (Semana de Ensino, Pesquisa e Extensão - UFSC - Universidade Federal de Santa Catarina). The workshop session lasted four hours, with an interval of 20 minutes, and the main objective was to provide participants (undergrad and post-grad students) with strategies to the construction of effective summaries from academic materials.

In the workshop, we briefly presented the theoretical model of Kintsch and van Dijk (1978) and van Dijk and Kintsch (1983), the textbase model and the situation model, using a power point presentation with succinct definitions, diagrams and examples. The focus was on the macrorules. We explored the text "Addiction: from mechanisms to treatment" (Nature Reviews Neuroscience, v.12, November 2011, p.621), and focused on reading strategies to be applied before reading, while reading and after reading. For instance, we exploited the text's layout, linking words and the way the author made his point. After that, we emphasized the four strategic questions to produce summaries proposed by Hill et al. (1982): (1) What is the author's goal?; (2) How does the author conduct the study?; (3) What are the findings of the study?; and (4) What are the implications of the results?. Participants received the material in the form of a handout. In addition, we instructed participants on the use of strategic linking words and phrases and the relationships they establish.

Participants took part in the construction of the summary of the text presented as a model. In order to monitor for comprehension, as well as to reinforce metacognitive abilities, participants reflected upon the product (sample summary provided by the researchers) and the relation of it with the theory presented. At this time we informed participants that we would like to use the summary they would be writing in sequence for a study on L2 reading comprehension and meaning construction. We asked for their permission via a written Consent Form, which was signed by all of them. It is relevant to mention that participants could continue participating in the workshop even though 
they did not allow their summary to be analyzed for the study. All participants signed the form voluntarily, and thus, their data will be analyzed in this paper.

Participants were instructed to produce their own summaries, individually, in the L2, English, of the authentic text "Brain Plasticity: how learning changes your brain"3 and were instructed to call up the strategic techniques and materials used during the presentation phase of the workshop. The chosen text fulfills the three criteria established by Kintsch and van Dijk (1978), since it is 1) sufficiently long (651 words) to ensure the involvement of macroprocesses in comprehension; 2) well structured; and 3) understandable without specific/technical knowledge. Participants were allowed to read the text as many times as needed; to use the strategies/material presented in the workshop; to write a maximum of 30 lines; and to use as much time as needed to produce the summary. It is important to highlight that participants had access to the text while producing the summaries.

As soon as participants finished writing their summaries, they were asked to answer a metacognitive questionnaire (ALMEIDA, 2010), designed to bring information regarding participants' background, their habits in reading in English, their own perception as readers of EFL and their opinion about the workshop.

Writing summaries is a widely used and valid instrument to evaluate global comprehension and the identification of central ideas in a text (KINTSCH; VAN DIJK, 1978; KOERICH; DELLAGNELO, 2008; SCHERER; TOMITCH, 2008; VAN DIJK; KINTSCH, 1983). We followed the advice given by Scherer and Tomitch (2008), that is, we set a limited number of 25 lines for writing the summary, in an attempt to emphasize the conciseness of the text genre. The model of analysis of the summaries produced by this study participants was created based on Kintsch and van Dijk (1978), Koerich and Dellagnelo (2008), and Winfield (2010). Comprehension in this framework is divided into three major parts: the controlling idea (CRI), the central ideas (CI) and the secondary ideas (SI). The controlling idea corresponds to the identification of the topic of the text; the central ideas correspond to the identification of the key ideas and the topic of the text; and secondary ideas correspond to the supporting ideas, the details provided by the author in the text.

\footnotetext{
3 Published in the website http://www.sharpbrains.com/blog/2008/02/26/brain-plasticity-how-
} learning-changes-your-brain/ accessed on October $16^{\text {th }}, 2012$. 
We, Brazilian PhD students in Linguistics who are familiar with studies on metacognitive strategies, summarization processes and theory (KINTSCH; VAN DIJK, 1978; VAN DIJK; KINTSCH, 1983), created a model of analysis. Each researcher read the text carefully and selected the controlling idea (CRI) of the text, the central ideas (CI) and the secondary ideas (SI). The four ratings were organized and an agreement was reached as regards the model of analysis for the summaries of the text chosen, as displayed in Tab. 1.

Table 1 - Model of analysis for the summaries

\begin{tabular}{|c|c|}
\hline Ideas & Propositions \\
\hline CRI & $\begin{array}{l}\text { Brain plasticity corresponds to the ability that the brain possesses to "change" during life, to } \\
\text { reorganize itself by forming new connections between brain cells. }\end{array}$ \\
\hline CI1 & Factors that may influence brain plasticity: genetic, the environment, a person's actions. \\
\hline CI2 & $\begin{array}{l}\text { Neuroplasticity may occur at three times: } 1 \text { ) beginning of life (early age) when the immature } \\
\text { brain organizes itself; } 2 \text { ) the compensation/maximization of functions observed in cases of brain } \\
\text { injuries; } 3 \text { ) through adulthood in learning and memorizing. }\end{array}$ \\
\hline CI3 & $\begin{array}{l}\text { Becoming an expert in a specific domain allows for improvement/growth in the brain areas that } \\
\text { deal with the specific type of skill. }\end{array}$ \\
\hline SI1 & The brain adapts itself due to experience, brain damage or recovery. \\
\hline SI2 & $\begin{array}{l}\text { Contrary to was believed, aging does not prevent the brain from changing. Learning allows the } \\
\text { brain to form new connections between neurons and the internal structure of the existing } \\
\text { connections can also change. }\end{array}$ \\
\hline SI3 & $\begin{array}{l}\text { In the case of taxi drivers, the brain region that was observed as having grown was the } \\
\text { hippocampus, which is an area involved in dealing with spatial information; whereas for the } \\
\text { musicians, temporal and parietal areas were affected. For bilinguals, the left inferior parietal } \\
\text { cortex was larger in comparison to monolinguals, while medical students presented alterations in } \\
\text { the parietal cortex and hippocampus, areas connected to learning and memory. }\end{array}$ \\
\hline
\end{tabular}

Each summary will be analyzed using this model and factors such as the number of lines, number of words, use of linking words and title will be taken into account in the analysis.

\subsection{Participants}

Eight university-level (UFSC) students participated in the study. Their mean age is 23.5 years old. From the pool, seven participants are women and just one is a man. Six participants were undergraduate students (two participants: Biology; three: Letras/Inglês; one: Architecture) at the time of data collection; one was taking her 
Masters in Nutrition and the remaining one had just finished her Masters in Nutrition and aimed at taking her Ph.D. in Biochemistry. The majority of participants have studied English as a foreign language in regular schools and language institutes for different periods of time (two participants: for seven years; two: for one year and a half; one: for six years; one: for four years). The remaining two participants learned English as a second language as they lived abroad for a certain period of time (one participant: five years; one: four months). Their proficiency levels ranged from pre-intermediate to advanced (as stated by the participants themselves). Unfortunately, due to time constraints, it was not possible to apply a proficiency test to evaluate participants' level of proficiency in English. Participants answered a metacognitive questionnaire as regards their reading behavior in English.

\section{Results and discussion}

\subsection{Metacognitive questionnaires}

As this study dealt with reading strategies and summary of an academic/scientific article, it is important to characterize our participants as regards their reading behavior as strategic readers (ALMEIDA, 2010) in the English language. Most participants are used to reading in English, as revealed by their statements: three participants like reading in English a lot and they are always reading something; one likes reading in English a lot, but only the material she chooses to read; two participants only read academic material that is requested by the professors; one sometimes reads in English, but she wishes she had more time to read. Just one participant reported rarely reading in English, as she prefers reading in Portuguese. As regards the academic texts they frequently read, the answer is a function of the stage they are in their academic life. The ones who are in the beginning of their undergraduate course read more chapters of books and course books while the ones who are more advanced in their studies, read more scientific journals and scientific publications online.

As regards proficient reading, it is relevant to emphasize that more skilled readers, who are likely to have more reading experiences, generally employ distinct reading strategies depending on their purpose and also on the genre of the text, as 
opposed to less skilled readers, who are not aware that the way they approach the written material should be guided by the text characteristics and reading purpose (CALDART, 2010; GRABE, 2009; NARVAEZ, 2002).

In relation to the time spent reading in English as a source of academic information, the great majority - five participants - spend from thirty minutes to one hour per day reading in English. Interestingly, two participants, who attend English Language and Literature undergraduate course, acknowledge reading less than thirty minutes per day in English and one participant, who is a Masters student in Nutrition, reads from one hour to two per day. In addition, all the participants affirmed reading academic material at home, but some of them also read at work (two participants), at the library (two), at the university (one) and while traveling from/to work/home (one).

As regards the reason why participants read academic texts in English, seven participants stated that they consider it a way to improve their knowledge of the language and that they read to get prepared for a class discussion or presentation as well as to learn about the theme of a class. Five participants declared that they read academic texts in English to write essays and/or research papers. Two participants revealed that they only read the material that their professors ask them to read and two participants that they only read before an exam.

We asked participants what strategies they employ when they encounter difficulties understanding texts in English. The majority of our participants indicate that they re-read the paragraph where they encountered problems in comprehension (seven participants); half the participants reported that they highlight the main ideas in the text while reading it (four). Also, a good number of participants stated that they do not worry that they did not understand something and continue reading the text (five). Frequently, they look for the meaning of some words in the dictionary while and after reading the text (seven). Surprisingly, the least frequently used strategies listed were making a summary of the text (five) and writing down the main ideas of the text (four). Interestingly, just one participant, a post-graduation student, affirmed writing summaries of what she reads.

Finally, when asked about their metacognitive perception as English readers, seven participants revealed they read in English in their knowledge area and they acknowledge that they do not understand every single word, and when the word 
hinders comprehension, they use the internet (translators, dictionaries) as a tool to improve their vocabulary. Just one participant reported a different answer: "I don't read much in English, only academic papers and usually I don't understand them. I look for words in the dictionary but I end up forgetting them later on" (answer to the questionnaire).

In a nutshell, results from the metacognitive questionnaire apparently indicate participants' awareness of the reading process, as strategic readers in EFL, as students at the tertiary level are expected to be. Furthermore, they indicate that participants seem to be able to perceive the demands of different genres, in this case, an expository text, and applying the adequate strategies to help them in various reading situations. However, a doubtful point that perhaps needed further investigation is the fact that participants replied using summaries as one of the least frequently used strategy, which may be a drawback when working with long, expository, academic texts as the ones students at the tertiary level are expected to read.

\subsection{Summaries}

Participants produced summaries that were analyzed using the framework created for this study. Tab. 2 presents the results in relation to the ideas of the text.

Table 2 - Analysis of the summaries produced by participants

\begin{tabular}{|c|c|c|c|c|c|c|c|c|c|}
\hline & P1 & P2 & P3 & P4 & P5 & P6 & P7 & P8 \\
\hline CRI & $\checkmark$ & $\checkmark$ & $\checkmark$ & $\checkmark$ & $\checkmark$ & $\checkmark$ & $\checkmark$ & $\checkmark$ \\
\hline CI1 & No & No & No & $\checkmark$ & $\checkmark$ & $\checkmark$ & No & $\checkmark$ \\
\hline CI2 & Incomplete & $\checkmark$ & Incomplete & $\checkmark$ & $\checkmark$ & $\checkmark$ & No & Incomplete \\
\hline CI3 & $\checkmark$ & $\checkmark$ & $\checkmark$ & $\checkmark$ & $\checkmark$ & $\checkmark$ & $\checkmark$ & No \\
\hline SI1 & $\checkmark$ & $\checkmark$ & No & $\checkmark$ & $\checkmark$ & $\checkmark$ & $\checkmark$ & $\checkmark$ \\
\hline SI2 & $\checkmark$ & $\checkmark$ & $\checkmark$ & $\checkmark$ & $\checkmark$ & $\checkmark$ & No & $\checkmark$ \\
\hline SI3 & $\checkmark$ & Incomplete & $\checkmark$ & Incomplete & No & No & Incomplete & Incomplete \\
\hline \# lines & 18 & 16 & 20 & 21 & 23 & 18 & 22 & 15 \\
\hline \# words & 172 & 93 & 147 & 192 & 252 & 98 & 121 & 114 \\
\hline
\end{tabular}

Note: CRI stands for the controlling idea of the text; CI stands for the central ideas; and SI stands for the secondary ideas of the text.

Results reveal that all participants were able to reproduce the controlling idea of the text $(100 \%)$ in their summaries, but not all of them wrote about the central and 
secondary ideas. It is worth pointing out that the CRI was explicitly expressed in the text in the manner of a topic sentence, perhaps facilitating its identification and retrieval. Furthermore, considering the fact that all participants were able to identify the CRI, and drawing on Kintsch and van Dijk's claim that "the propositions of a text base must be connected relative to what is intuitively called a topic of discourse" (KINTSCH; VAN DIJK, 1978, p. 366), we would presuppose that the participants in this research had the initial necessary conditions for successful text processing.

However, results for Central idea 1 (Factors that may influence brain plasticity: genetic, the environment, a person's actions) run counter to what was abovementioned, because CI1 was reproduced by only four participants (50\%) while the remaining four simply did not mention it in their summaries. Part of the difficulty in the identification of CI1 may be related to the fact that CI1 represents a superordination of ideas from the text, which, according to Kintsch and van Dijk (1978), requires inference generation at local and global levels. In offering a description of the construction of the semantic structure of the text, Kintsch and van Dijk (1978) explain that, in addition to identifying the discourse topic, comprehenders need to reduce and organize input information from the text, relate it the discourse topic, which will lead to the construction of a macrostructure of the text. Having said that, it is important to acknowledge that not all the elements of CI1 were extensively explored in the text, in particular "the environment" factor. For this reason, we speculate that making processing of this specific information more difficult because readers probably needed to generate more inferences to compensate for the limited information on the aforementioned factor.

Results for Central idea 2 also indicate some processing difficulties. More specifically, Central idea 2 (Neuroplasticity may occur at three times: 1) beginning of life (early age) when the immature brain organizes itself; 2) the compensation/maximization of functions observed in cases of brain injuries; 3) through adulthood in learning and memorizing) was mentioned by four participants, partly mentioned by three, thus $68.75 \%$ of the participants, and not mentioned at all by one of the participants. Seven participants (87.5\%) mentioned central idea 3 (Becoming an expert in a specific domain allows for improvement/growth in the brain areas that deal with the specific type of skill). As regards the details, the secondary ideas 1 and 2 were the most mentioned (87.5\% each) while the secondary idea 3 was completely described 
by two participants, partially by four, thus (50\%) and not described by two of the participants. It seems that participants concentrated on the controlling idea and a little more on the secondary ideas than the central ones. This finding may be explained due to the fact that secondary ideas involved examples that illustrated the central ideas and, this way, may have reinforced the information, preventing participants from clearly stating the central ideas.

In order to identify central ideas from the text presented in this research, readers would have to condense information from example and to connect them to the controlling idea of the text while producing their summaries. Based on models of comprehension previously reviewed in this article, this would entail chunking information and integrating at local and global levels into a coherent representation, which may render the identification of central ideas in the more demanding text (GAGNÉ et al., 2993; KINTSCH; VAN DIJK, 1978; VAN DIJK; KINTSCH, 1983).

As regards the size of the summaries, the mean of lines is 19.1 (min: 16 / max: 23 ) and the mean of words is 148.6 (min: 93 / max: 252). Participants had access to the text while producing the summaries and could use as much time as needed to write it (maximum of one hour). It is interesting to compare the summaries produced by P5 and P6. P5 produced the longest summary and P6 one of the shortest summaries. Both participants included the same ideas in their summaries, except for not mentioning SI3; thus, it is possible to argue that P6 could effectively summarize the text, which means, using fewer words. In turn, P7 produced a summary 'cutting and pasting' sentences from the original text, reproducing only one of the central ideas, and one and half of the secondary ideas, which shows a lack of integrative and summarization inferences in the summarization of the text as postulated by Gagné et al. (1993), Kintsch and van Dijk (1978), van Dijk; Kintsch (1983). Also, similar results had been observed in previous studies (KOERICH; DELLAGNELLO, 2008; WINFIELD, 2010).

Summaries in a 'cut and paste' fashion, i.e., when individuals simply copy sentences from the original text, reveal that the participant may have not created a coherent mental representation of the text, since she could not differentiate central from secondary ideas, neither use the macrorules to get the gist of the text, and as a result, wrote a summary that was a verbatim reproduction of some ideas of the text. Proficiency might have played a role in this result, since the participant reported having 
studied English for only one year and a half. Even so, more data is needed to confirm this hypothesis.

Most of the participants (five) gave their summary a title or indicated in the first paragraph of their summaries the text they were summarizing. The remaining three participants did not indicate in their summaries what the original text was. Besides, throughout their summaries, participants made use of the linking words and phrases, as they were instructed in the workshop. All participants made use of words and phrases that established a relationship of addition (in addition, moreover, furthermore) and of cause and effect (as a result of, due to, because, in other words). Just two participants made use of a meaningful order to write their summaries (first, second, next, finally); and only one used an adversative linker (however). In fact, studies including the use adversative linkers in comprehension presented results that confirm the scarce use of adversative conjunctions in comparison to other types (for further discussion refer to Murray, 1995; Winfield, 2010). In addition, three participants included a concluding paragraph in their summaries, indicated by expressions such as in conclusion, to sum it up, summing up.

Our hypothesis that the participants would be able to construct a meaningful and coherent representation of the text as reflected in their production of summaries is partially confirmed since the great majority of participants could include the controlling idea $(100 \%)$, central ideas $(50 \%, 68.75 \%, 87.5 \%)$ and secondary ideas $(87.5 \%, 87.5 \%$, $50 \%$ ) in their summaries. Our findings run counter to those from Koerich and Dellagnelo (2008) that found that participants could not perceive the difference between main ideas and details independently of the language (Portuguese and English) and had difficulties in producing appropriate summaries.

Although it was not possible to assess participants' proficiency with a test, we based ourselves on the data collected by means of the metacognitive questionnaire to say that the participants may have assumed strategic reading behavior when writing their summaries. Results show that all participants could identify and produce the controlling idea of the text, whereas most of them could identify and recall the central ideas.

Moreover, results indicate that participants appear to have the required declarative knowledge on the concept of the summary task, because they were able to 
identify the main ideas to construct a meaningful representation of the text. In addition, participants also demonstrate having procedural knowledge applied to the reading situation (ALMEIDA, 2010), since they seemed strategic in successfully writing their summaries.

From the practice provided in the workshop it seems possible to assume that the experience not only may have helped participants to understand the genre, but it also may have provided them with the tools to identify the controlling idea, the central and secondary ideas. This fact is revealed by P1, who wrote in her questionnaire: "I could really improve the way to write summaries and abstracts". Furthermore, it is believed that providing practice in reading and in writing may aid students in the understanding that writing a summary involves producing a macrostructure that expresses the central ideas of a text in a coherent and meaningful manner.

\section{Final remarks: limitations, suggestions for future research and pedagogical implications}

The purpose of the present study was to investigate to what extent Brazilian university-level students were strategic when writing summaries of an expository text. The participants took part in a workshop at the $11^{\text {th }}$ SEPEX, at UFSC, about producing effective summaries from academic texts. They were undergraduate and post-graduate students from different courses and had the objective of writing appropriate summaries of the academic texts they read in their specific areas. These participants received instruction on how to identify the main ideas in a text, on how to use the macrorules proposed by Kintsch and van Dijk (1978), and on the use of linking words and phrases. They practiced and then were required to produce a summary of an expository text on brain plasticity and learning and to answer a metacognitive questionnaire. It was hypothesized that the summaries produced by these participants would reveal their metacognitive awareness in the use of effective strategies, ability which as reflected in constructing a meaningful and coherent representation of the text via writing a summary.

Results revealed that most of the participants could include in their summaries the controlling idea, the central and secondary ideas of the text chosen, while employing 
the strategies taught during the workshop. Participants showed knowledge about the genre and some of them could better summarize the ideas than the others, as the participant that used the same ideas using fewer words if compared to the participant that wrote the longest summary. In addition, participants made use of the list of linking words and phrases provided in the workshop to mark the relationships between ideas in their summaries. Participants who considered themselves to be more active readers of English material seemed to have better performance in summarizing. It seems also important to emphasize that despite the expository text chosen "Brain Plasticity: how learning changes your brain" was a lay-person-reading type of text, the information it contained was not so simple to be recalled, mainly for those participants who were not in contact with such kind of reading.

As regards the limitations, this study analyzed a reduced number of productions, just eight, a fact that does not allow for the establishment of conclusive data. In addition to that, we could not test the participants' ability to produce summaries before the workshop. Moreover, we could not further enquire participants why they reported using summaries as one of the least frequent strategies. Future studies should pre-test participants before instruction, as a way of comparing their performance before and after instruction. Nonetheless, the ability to produce summaries is considered inherent to proficient readers, as they are presumably able to extract the main ideas from texts.

As another limitation, these researchers could not properly control for the participants' level of proficiency. Although it was stated in the abstract submitted to the evaluation committee of the event (Appendix A), participants should have had at least an intermediate level of English to take part in the workshop. Future studies should attempt to control for proficiency. In addition, it would be interesting to assess the participants' working memory capacity with the objective of testing the extent to which higher working memory capacity would result in more efficient summarization. Working memory capacity has been consistently shown in the literature to be one of the factors contributing to efficient performance in reading-related tasks (BAILER, 2011; DANEMAN; CARPENTER, 1980; TOMITCH, 2003; TORRES, 2003, to mention but a few).

As pedagogical implications, teaching students how to produce summaries, providing them with the tools to understand the controlling idea and to differentiate central from secondary ideas, and offering them instruction on linking words and 
phrases may aid in the development of more competent and strategic readers. Providing university-level students with instruction on the elaboration of summaries turns out to be relevant, since it is an academic ability these students ought to display. Not only in the universities should this ability be taught, but also at schools, so that students understand that producing a summary involves producing a macrostructure that articulates the central ideas of a text in a coherent and meaningful manner.

Even though some limitations were presented, and despite being a small scale research, it is believed that this study contributed to a greater understanding of the reading and writing processes of EFL university-level Brazilian students.

\section{References}

AEBERSOLD, Jo Ann; FIELD, Mary Lee. From reader to reading teacher: issues and strategies for second language classrooms. New York: Cambridge University Press, 1997.

ALMEIDA, Fabiana Vanessa Achy de. University students' perception of their reading behavior in EFL. 2010. 197f. Dissertação (Mestrado em Língua Inglesa e Literatura Correspondente) - Pós-graduação em Letras/Inglês e Literatura Correspondente, Universidade Federal de Santa Catarina, Florianópolis, 2010. Disponível em: http://www.tede.ufsc.br/teses/PLLE0467-D.pdf

BAILER, Cyntia. Working memory capacity and attention to form and meaning in EFL reading. 2011. 161f. Dissertação (Mestrado em Língua Inglesa e Literatura Correspondente) - Pós-graduação em Letras/Inglês e Literatura Correspondente, Universidade Federal de Santa Catarina, Florianópolis, 2011. Disponível em: http://www.tede.ufsc.br/teses/PLLE0484-D.pdf

BARETTA, Luciane. The performance of proficient EFL readers when reading to recall and summarize expository texts. 1998. 178f. Dissertação (Mestrado em Língua Inglesa e Literatura Correspondente) - Pós-graduação em Letras/Inglês e Literatura Correspondente, Universidade Federal de Santa Catarina, Florianópolis, 1998. Disponível em: http://tede.ufsc.br/teses/PLLE0170-D.pdf

CALDART, Deise. The effect of genre expectation on EFL Brazilian students' inference generation and reading comprehension. 2012. 156f. Dissertação (Mestrado em Língua Inglesa e Literatura Correspondente) - Programa de Pós Graduação em Letras/Inglês e Literatura Correspondente, Universidade Federal de Santa Catarina, Florianópolis, 2012. Disponível em: http://www.tede.ufsc.br/teses/PLLE0491-D.pdf

CARRELL, Patricia. Can strategies be successfully taught? Australian Review of Applied Linguistics, 21, (1), p. 1-20, 1998. 
CARRELL, Patricia. Interactive text processing. In: CARRELL, Patricia L.; DEVINE, Joanne; ESKEY, David E. (Eds.), Interactive Approaches to Second Language Reading. New York: Cambridge University Press, 1998, p. 239-259.

CARRELL, Patricia. Metacognitive awareness and second language reading. The Modern Language Journal, 73 (2), p. 121-134, 1989. Retrieved on November 11 th 2008 , from http://www.jstor.org/pss/326568.

COHEN, Andrew. Strategies in learning and using a second language. New York: Longman, 1998.

COHEN, Andrew; GLASMAN, Hilary; ROSENBAUM-COHEN, Phyllis R.; FERRARA, Jonathan; FINE, Jonathan. Reading English for specialized purposes: discourse analysis and the use of student informants. In: CARRELL, Patricia L.; DEVINE, Joanne; ESKEY, David E. (Eds.), Interactive Approaches to Second Language Reading. New York: Cambridge University Press, 1998, p. 152-167.

DANEMAN, Meredyth; CARPENTER, Patricia A. Individual differences in working memory and reading. Journal of Verbal Learning and Verbal Behavior, 19(4), p. 450-466, 1980.

DEVINE, Joanne. The relationship between general language competence and second language reading proficiency: implications for teaching. In: CARRELL, Patricia L.; DEVINE, Joanne; ESKEY, David E. (Eds.), Interactive Approaches to Second Language Reading. New York: Cambridge University Press, 1998, p. 127-139.

EISTERHOLD, Joan Carson. Reading-writing connections: Toward a description for second language learners. In KROLL, Barbara (Ed.), Second language writing: research insights for the classroom. New York: CUP, 1990, p. 88-102.

GAGNÉ, Ellen D.; YEKOVICH, Carol Walker; YEKOVICH, Frank R. The cognitive psychology of school learning. New York: Harper Collins College Publishers, 1993.

GRABE, William. Reading in a second language: moving from theory to practice. New York: Cambridge University Press, 2009.

HILL, Susan S.; SOPPELSA, Betty F.; WEST, Gregory K. Teaching ESL students to read and write experimental research papers. Tesol Quarterly, 16(3), p. 333-347, 1982.

KINTSCH, Walter; VAN DIJK, Teun. Toward a Model of Text Comprehension and Production. Psychological Review, 85(5), p. 363-394, 1978.

KODA, Keiko. Insights into second language reading: A cross-linguistic approach. New York: Cambridge University Press, 2008.

KOERICH, Rosana Denise; DELlAGNELlO, Adriana Kuerten. A habilidade de identificar idéias centrais em textos em português (L1) e em inglês (L2): um estudo comparativo. 
In: TOMITCH, L.M.B. (Ed.), Aspectos cognitivos e instrucionais da leitura. São Paulo, Brazil: EDUSC, 2008, p. 213-231.

MURRAY, John D. Logical connectives and local coherence. In: LORCH, Robert F.; O'BRIEN, Edward J. (Eds.), Sources of coherence in reading. Hillsdale: Lawrence Erlbaum, 1995, p. 107-126.

NARVAEZ, Darcia. Individual differences that influence reading comprehension. In: PRESSLEY, Michael; BLOCK, Cathy Collins. (Eds.). Reading Comprehension Instruction: research-based best practices. New York: Guilford, 2002, p. 158-175.

PARIS, Scott G., LIPSON, Marjorie Y., WIXSON, Karen K. Becoming a Strategic Reader. Contemporary Educational Psychology, 8, p. 293-316, 1983.

PARIS, Scott G., WASIK, Barbara A.; TURNER, Julianne C. The development of strategic readers. In: BARR, Rebecca, KAMIL, Michael L., MOSENTHAL, Peter B.; PEARSON, David. (Eds.), Handbook of Reading Research, vol. 2. New York: Longman, 1991, p.609-640.

ROSENSHINE, Barak; MEISTER, Carla. Cognitive Strategy Instruction in Reading. In: STAHL, Steven A., \& HAYES, David A. (Eds.). Instructional models in reading. New Jersey, USA: Lawrence Erlbaum Associates, 1997, p. 85-108.

RUMELHART, David Everett. Schemata: the building blocks of cognition. In: GUTHRIE, John T. (Ed.). Comprehension and teaching: research reviews. Newark: International Reading Association, 1981, p. 3-26.

SCHERER, Lilian; TOMITCH, Lêda Maria Braga. A coesão textual e seus reflexos na elaboração de resumos. In: TOMITCH, Lêda Maria Braga (Ed.), Aspectos cognitivos e instrucionais da leitura. São Paulo, Brasil: EDUSC, 2008, p. 99-123.

TOMITCH, Lêda Maria Braga. Reading: text organization perception and working memory capacity. Florianópolis, SC: PGI/UFSC, ARES - Advanced Research in English Series, 2003.

TOMITCH, Lêda Maria Braga (Org.) Aspectos cognitivos e instrucionais da leitura. Bauru, SP: EDUSC, 2008.

TORRES, Ana Cecília da Gama. (2003) Working memory capacity and reader's performance on main idea construction in L1 and L2. 2003. 289f. Tese (Doutorado em Língua Inglesa e Linguística Aplicada) - Pós-graduação em Letras/Inglês e Literatura Correspondente, Universidade Federal de Santa Catarina, Florianópolis, 2003. Disponível em: http://www.tede.ufsc.br/teses/PLLE0292.pdf

URQUHART, Sandy; WEIR, Cyril. (1998). Reading in a second language: process, product and practice. New York: Longman.

VAN DEN BROEK, P.; RISDEN, K.; HUSEBYE-HARTMANN, E. The role of readers' standards for coherence in the generation of inferences during reading. In: LORCH, 
Robert F.; O'BRIEN, Edward J. (Eds.), The construction of mental representations during reading. New Jersey, USA: LEA, 1995, p. 353-373.

VAN DIJK, Teun; KINTSCH, Walter. Strategies of discourse comprehension. New York: Academic Press, 1983.

WINFIELD, Claudia Marchese. The impact of conjunctions on EFL university students' comprehension and summarization of expository texts. 2010. 160f. Dissertação (Mestrado em Língua Inglesa e Literatura Correspondente) - Pós-graduação em Letras/Inglês e Literatura Correspondente, Universidade Federal de Santa Catarina, Florianópolis, 2010. Disponível em: http://www.tede.ufsc.br/teses/PLLE0456-D.pdf

Recebido em março de 2014.

Aceito em junho de 2014.

\section{Appendix A - The workshop abstract submitted to the evaluation committee}

Como escrever bons resumos em inglês como língua estrangeira?

(How to write effective summaries in English as a foreign language?)

$$
\begin{array}{r}
\text { Claudia Marchese Winfield (UFSC - PGI - NEL - CNPQ) } \\
\text { geoffclau@hotmail.com } \\
\text { Cyntia Bailer (UFSC - PGI - NEL - CAPES/REUNI) } \\
\text { cyntiabailer@gmail.com } \\
\text { Deise Caldart Roscioli (UFSC - PGI - NEL - CAPES/REUNI) } \\
\text { deise.caldart@hotmail.com } \\
\text { Fabiana Vanessa Achy de Almeida (UFSC - PGI - NEL - CAPES) } \\
\text { almeida.fabiana@uol.com.br }
\end{array}
$$

Esta oficina, ministrada em inglês, resulta do trabalho do grupo de pesquisa em Leitura (NEL: Núcleo de Estudos em Leitura e Escrita), sob orientação da Profa. Dra. Lêda Maria Braga Tomitch. Apresentamos uma proposta de como o aluno universitário pode construir bons resumos de textos acadêmicos, a partir do modelo de leitura e produção de resumos proposto por Kintsch e van Dijk (1978), no qual o resumo é entendido como um processo de compreensão. A partir de perguntas fundamentais voltadas à leitura do texto científico, trabalharemos com o gênero textual, com foco em questões de produção, de construção de resumos. A oficina é hands-on, já que os participantes terão a oportunidade de 'colocar a mão na massa', usar as estratégias propostas e construir seus próprios resumos. Para participar da oficina, é necessário ter nível intermediário de inglês.

Palavras-chave: leitura, produção de resumos, texto científico. 